\title{
Strategi Pengembangan Laboratorium Program Studi Teknik Industri di Universitas Al Azhar Indonesia
}

\author{
Nunung Nurhasanah", Octrivia Deliani \\ Program Studi Teknik Industri, Fakultas Sains dan Teknologi, \\ Universitas Al Azhar Indonesia, Jl. Sisingamangaraja, Jakarta 12110 \\ E-mail: nunungnurhasanah@uai.ac.id
}

\begin{abstract}
Abstrak - Praktikum merupakan mata kuliah yang berdiri sendiri menjadi suatu mata kuliah praktikum, atau embedded dalam suatu mata kuliah. Kurikulum Teknik Industri tahun akademik 2010/2011 yang terdiri dari total 144 sks, di dalamnya terdapat $19 \%$ mata kuliah praktikum atau sebanyak 28 sks. [1]
\end{abstract}

Tujuan penelitian ini adalah untuk merumuskan strategi pengembangan laboratorium Teknik Industri di UAI sehingga tercapai visi untuk menjadi program studi Teknik Industri terkemuka dalam menghasilkan lulusan sarjana teknik industri yang unggul dan bermartabat serta memiliki kemampuan Intelektual di bidang Sistem Manufaktur dan Manajemen Bisnis yang berlandaskan nilai-nilai spiritual, moral, dan etika Islam.

Penelitian ini menggunakan pendekatan metodologi penelitian manajemen strategi dan analisis keputusan. Pendekatan yang digunakan dalam manajemen strategi adalah menganalisis faktor lingkungan eksternal dan internal dengan matriks IFE dan EFE. Matriks ini akan menghasilkan nilai koordinat sebesar $(0,48$ : 0,90) yang akan digambarkan dengan Grand strategy matrix. Berdasarkan grand strategy matrix diperoleh posisi Lab TI-UAI pada kuadran I.

Strategi yang ditawarkan dari hasil brainstorming adalah Strategi penetrasi pasar, pengembangan pasar dan pengembangan produk. Berdasarkan hasil penggabungan pendapat pakar dengan pendekatan Non Numeric Multicriteria Decision Making diperoleh prioritas strategi pengembangan Penetrasi pasar dan Pengembangan produk dengan nilai $P$ (Penting).
Abstract - Practicum is a subject that can be a practicum courses, or embedded in a course. Industrial Engineering curriculum academic year 2010/2011 which consists of a total of 144 credits, has $19 \%$ included a practicum courses or as many as 28 credits. [1]

The purpose of this study is to formulate a development strategy Industrial Engineering laboratories in UAI in order to reach the vision to become a leading Industrial Engineering courses in industrial engineering graduates produced superior and dignified and intellectual ability in the field of Manufacturing and Business Management System which is based on spiritual values, morals, and ethics of Islam.

This research approach strategic management research methodologies and decision analysis. The approach used in the management strategy is to analyze the internal and external environmental factors with the IFE matrix and EFE. This matrix will result in the value of the coordinate of $(0.48: 0.90)$ to be represented by Grand strategy matrix. Based on the grand strategy matrix obtained by positioning Lab IEUAI in quadrant $I$.

Strategies are offered from the brainstorming strategy of market penetration, market development and product development. Based on the incorporation of expert opinion approach to Non Numeric Multicriteria Decision Making gained priority strategy development Market penetration and product development with a value of $P$ (Important).

Keywords - Strategy, ratio, utility, laboratory, expert judgment, decision analysis 


\section{PENDAHULUAN}

$\mathrm{L}$ aboratorium merupakan salah satu sarana dan prasarana penting dalam perkuliahan, terutama bagi Program Studi (Prodi) Teknik Industri. Struktur mata kuliah program sarjana strata 1 Teknik Industri di Universitas Al Azhar Indonesia (UAI) memiliki total 144 sks, terdiri dari 132 sks mata kuliah inti, 9 sks mata kuliah peminatan dan 3 sks mata kuliah pilihan.

Praktikum merupakan mata kuliah yang berdiri sendiri menjadi suatu mata kuliah praktikum, atau embedded dalam suatu mata kuliah. Kurikulum Teknik Industri tahun akademik 2010/2011 yang terdiri dari total 144 sks, di dalamnya terdapat $19 \%$ mata kuliah praktikum atau sebanyak 28 sks. [1]

Saat ini, prodi Teknik Industri memiliki 2 Laboratorium mandiri, yaitu Laboratorium Teknik Industri di Lantai 6 dan Laboratorium Proses Manufaktur-Ergonomi di Lantai B2. Laboratorium Teknik Industri digunakan untuk 6 jenis praktikum, yaitu: Praktikum Sistem Perancangan Kerja, Perancangan Teknik Industri I, Perancangan Teknik Industri II, Perencanaan \& Pengendalian Produksi, Perencanaan Sumber Daya Perusahaan dan Perancangan Tata Letak Pabrik. Laboratorium Proses Manufaktur-Ergonomi digunakan untuk 3 jenis praktikum, yaitu: Praktikum Dasar Perancangan Teknik Industri, Proses Manufaktur dan Ergonomi.

Praktikum yang tidak dilaksanakan di kedua Laboratorium tersebut adalah: Praktikum Fisika Dasar I-II, Dasar Pemrograman, Statistik Industri dan Simulasi Komputer. Praktikum Fisika I-II dilaksanakan di Laboratorium Fisika yang penggunaannya dilaksanakan oleh semua prodi yang ada di Fakultas Sains dan Teknologi (FST).

Praktikum Dasar Pemrograman, Statistik Industri dan Simulasi Komputer dilaksanakan di Laboratorium Puskom di Lantai 6 yang dikelola oleh Pusat Komputer dan Sistem Informasi (PKSI) UAI. Penggunaan laboratorium Puskom diperuntukkan bagi seluruh Prodi di UAI.

Data jumlah mahasiswa prodi Teknik Industri yang trendnya secara rata-rata meningkat sejak tahun 2007 hingga 2010, yaitu: 6, 24, 21 dan 34 mahasiswa, atau $18,24 \%$ pertahunnya. Tetapi, peningkatan ini belum disertai dengan peningkatan sarana dan prasarana laboratorium. Hal ini terurai dari data penggunaan dan ketersediaan laboratorium untuk praktikum prodi Teknik Industri berdasarkan kurikulum TA 2010/2011 yang telah disebutkan dalam paragraf sebelumnya.

Mata kuliah prodi TI tidak hanya dikembangkan bagi pendalaman kompetensi mahasiswa, sehingga tercapai visi dan misi prodi TI untuk menjadi program studi Teknik Industri terkemuka dalam menghasilkan lulusan sarjana teknik industri yang unggul dan bermartabat serta memiliki kemampuan Intelektual dibidang Sistem Manufaktur dan Manajemen Bisnis yang berlandaskan nilai-nilai spiritual, moral, dan etika Islam. Untuk dapat mencapai hal ini, maka sudah saatnya untuk merumuskan strategi pengembangan laboratorium Teknik Industri di UAI.

Bagaimana merumuskan strategi pengembangan laboratorium Teknik Industri UAI agar memenuhi standar minimal Dikti, memiliki daya saing sehingga mampu berkompetisi dengan PTS yang ada di wilayah DKI Jakarta, dan mencapai visi untuk menjadi program studi Teknik Industri terkemuka dalam menghasilkan lulusan sarjana teknik industri yang unggul dan bermartabat serta memiliki kemampuan Intelektual di bidang Sistem Manufaktur dan Manajemen Bisnis yang berlandaskan nilai-nilai spiritual, moral, dan etika Islam.

Tujuan penelitian ini adalah untuk merumuskan strategi pengembangan laboratorium Teknik Industri di UAI sehingga tercapai visi untuk menjadi program studi Teknik Industri terkemuka dalam menghasilkan lulusan sarjana teknik industri yang unggul dan bermartabat serta memiliki kemampuan Intelektual di bidang Sistem Manufaktur dan Manajemen Bisnis yang berlandaskan nilai-nilai spiritual, moral, dan etika Islam.

Penelitian ini diharapkan dapat memberikan masukan kepada UAI, khususnya kepada prodi Teknik Industri mengenai rumusan strategi pengembangan laboratorium TI. Dengan strategi pengembangan yang dirumuskan melalui dana riset Grant LP2M ini, diharapkan prodi TI dapat mencapai visi misi yang telah ditetapkannya.

Penelitian ini menggunakan laboratorium TI-UAI sebagai objek penelitian, sehingga lokasi penelitian adalah di lingkungan UAI. Penelitian ini akan menggunakan pendekatan Teori Utility untuk menganalisis kondisi saat ini. Pemetaan posisi laboratorium TI-UAI akan dilaksanakan dengan 
menggunakan Grand Strategy Matrix. Prioritas strategi akan dilaksanakan dengan menggunakan pendekatan Non Numeric ME-MCDM.

\section{TINJAUAN PUSTAKA}

\subsection{Penelitian Terdahulu}

Penelitian terdahulu yang pernah dilakukan mengenai penggunaan pendekatan manajemen startegi di bidang pendidikan tinggi adalah penelitian yang dilakukan oleh [2] menyatakan bahwa pendidikan mempunyai peran yang sangat penting dalam meningkatkan kualitas sumber daya manusia, semakin tinggi pendidikan suatu bangsa semakin tinggi pula tingkat kemakmuran. Dalam beberapa tahun terakhir terdapat fenomena pada Perguruan Tinggi Swasta yaitu adanya fluktuasi jumlah mahasiswa baru.

Dengan adanya fenomena tersebut yang berkepanjangan akan menimbulkan risiko atau dampak yang berpengaruh pada keuangan organisasi dan biaya belajar-mengajar. Dengan demikian organisasi harus mempunyai strategi yang selalu dievaluasi dan dirumuskan ulang untuk dapat bersaing dengan yang lainnya. Tujuan dari penelitiannya adalah untuk mengetahui kesesuaian antara perumusan strategi dan implementasi strategi universitas Merdeka Malang; untuk mengetahui perumusan strategi pada Universitas Merdeka Malang; untuk merumuskan strategi baru bagi Universitas Merdeka Malang. Metode penelitian yang digunakan adalah jenis deskriptif kualitatif dengan menggunakan metode studi kasus. Hasil dari analisa evaluasi strategi bahwa asumsi kondisi internal dan eksternal dari beberapa unsur yang digunakan oleh Universitas Merdeka Malang mengalami perubahan yang besar. Dengan adanya perubahan tersebut maka perlu perumusan strategi yang baru bagi Universitas Merdeka Malang.

Hasil dari perumusan strategi yang menggunakan beberapa alat analisis, seperti Matrik EFE, Matriks IFE, SWOT/TOWS, Matrik SPACE, Matrik IE, dan Matrik QSPM maka telah menghasilkan beberapa alternatif strategi yang dapat dipilih oleh Universitas Merdeka Malang.

Kesimpulan dari penelitian ini adalah dari evaluasi strategi menghasilkan adanya perbedaan asumsi unsur pada kondisi asumsi internal dan eksternal dengan kondisi internal pada saat ini dan masa mendatang universitas Merdeka Malang. Dari hasil perumusan strategi dengan menggunakan beberapa alat analisis strategi, bahwa strategi yang sesuai dengan kondisi Universitas Merdeka Malang adalah strategi intensif.

\subsection{Definisi Laboratorium}

[3] menyatakan bahwa laboratorium merupakan ruangan baik tertutup maupun terbuka yang dirancang sesuai dengan kebutuhan untuk melakukan aktivitas yang berkaitan dengan fungsifungsi pendidikan, penelitian dan pengabdian kepada masyarakat. Aktivitas yang dimaksud adalah kegiatan yang saling terintegrasi, serta ditunjang oleh adanya suatu infrastruktur yang dibutuhkan demi terwujudnya hasil optimal. Laboratorium di perguruan tinggi adalah tempat berlangsungnya kegiatan praktikum dan penelitian yang mendukung pembelajaran dan pengembangan keilmuan. Laboratorium di tingkat perguruan tinggi merupakan laboratorium pendidikan dan pengajaran difokuskan pada pembelajaran bagi mahasiswa-mahasiswa S-0, S-1, S-2 dan S-3.

Program pendidikan engineering tanpa praktikum akan menjadi program pendidikan applied mathematics. Tujuan dari pendidikan engineering adalah memberikan pengalaman praktek engineering, dan laboratorium merupakan salah satu tempat untuk mendapatkannya. Dengan demikian, dalam laboratorium mahasiswa dapat mempraktekkan metode-metode engineering yang merupakan jantung dari program pendidikan engineering.

Laboratorium dan aktivitas atau tugas perancangan (design) merupakan inti dari proses pendidikan di fakultas atau jurusan teknik (engineering education). Praktek engineering yang pokok adalah kegiatan perancangan (design). Kegiatan ini menjadi pembeda utama profesi engineering dengan profesi yang lain.

\section{METODE PENELITIAN}

Penelitian ini merupakan usulan yang akan diberikan kepada prodi TI-UAI mengenai rumusan strategi pengembangan laboratorium. Strategi yang diusulkan akan diberikan dalam 3 alternatif strategi pengembangan. Strategi ini diusulkan berdasarkan analisis kondisi Laboratorium TI saat ini dan benchmark dengan 5 PTS. 
Ketiga strategi pengembangan ini akan diprioritaskan dengan menggunakan pendekatan ME-MCDM, yang diperoleh melalui penggabungan pendapat pakar. Pakar yang akan dimintai pendapat adalah Kaprodi TI-UAI, Koordinator Laboratorium TI-UAI dan Kepala Biro Akademik UAI.

Selain pendapat pakar, standar minimum laboratorium TI yang sudah disepakati dalam forum Badan Koordinasi Teknik Industri (BKSTI), juga dijadikan sebagai acuan dalam perumusan strategi pengembangan laboratorium TI-UAI. Diagram metodologi penelitian disajikan pada Gambar 1.

Analisis kondisi saat ini dilakukan dengan cara wawancara, pengumpulan data tertulis dan benchmark. Wawancara kepada Kepala prodi TI, Koordinator akademik TI, Koordinator laboratorium TI, serta Kepala Biro Sarana dan Prasarana UAI, akan dilakukan langsung oleh ketua tim peneliti. Sedangkan, pengumpulan data inventaris laboratorium TI-UAI akan dilaksanakan oleh mahasiswa selaku anggota tim peneliti

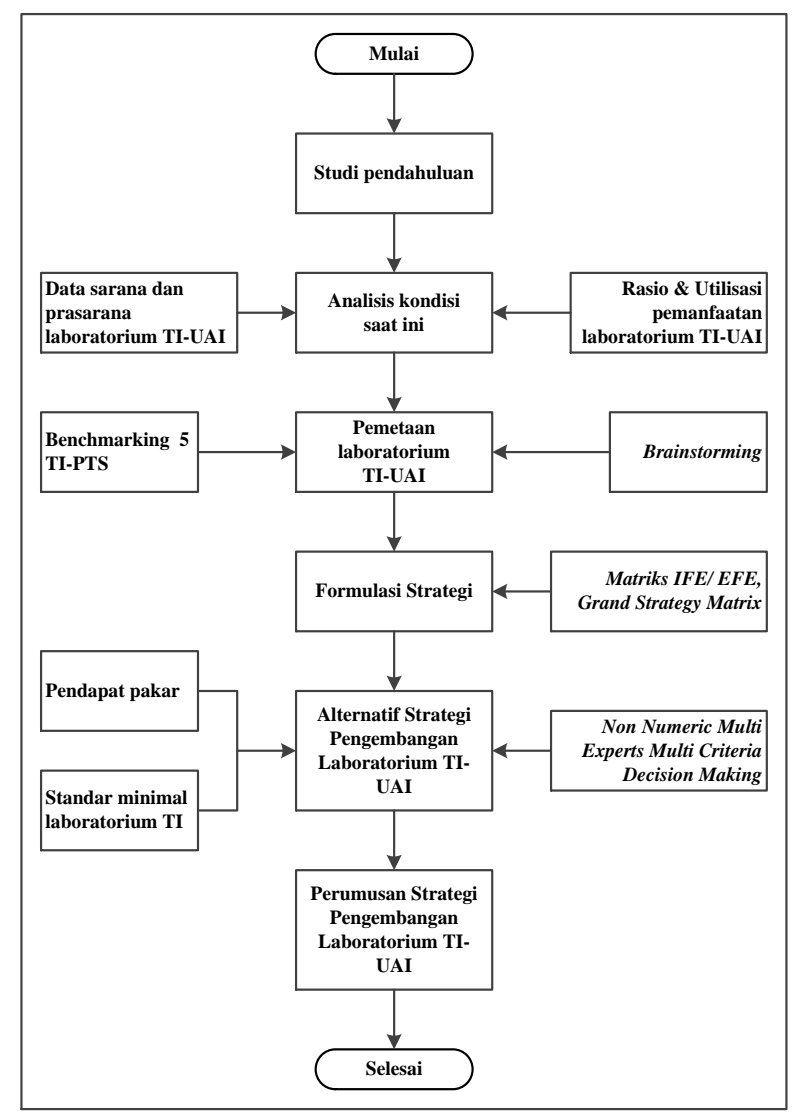

Gambar 1. Metodologi Penelitian Strategi Pengembangan Laboratorium TI-UAI
Kegiatan benchmarking ke 4 PTS yang tersebar di Jakarta dan 1 PTS yang berlokasi di Bandung akan dilakukan langsung oleh Ketua Peneliti. Metode pengumpulan data yang dilakukan adalah wawancara dan observasi lapangan ke masingmasing laboratorium yang terdapat di 5 PTS tersebut.

Pendekatan yang akan digunakan dalam pemetaan laboratorium TI adalah menggunakan teori manajemen strategi. Dalam menentukan posisi laboratorium TI-UAI saat ini berada, matriks yang akan digunakan Grand Strategy Matrix. Sebelumnya, harus dilakukan analisis lingkungan internal dan eksternal laboratorium TI-UAI terlebih dahulu.

Analisis lingkungan internal dikembangkan berdasarkan hasil wawancara dan pengumpulan data mengenai sarana dan prasarana laboratorium TI-UAI, serta segala hal yang terkait dengan laboratorium. Segala hal yang dimaksud di sini adalah prosedur penggunaan sarana dan prasarana laboratorium, prosedur pelaksanaan praktikum, prosedur perawatan sarana dan prasarana, penjadwalan, penyusunan modul, serta pengayaan konten praktikum.

Analisis eksternal dikembangkan berdasarkan standard minimum laboratorium Teknik Industri yang telah ditentukan oleh DIKTI dan disepakati melalui forum BKSTI. Proses pengadaan sarana dan prasarana laboratorium, dan kerjasama yang telah ataupun akan dilakukan dengan instansi pemerintah atau non pemerintah.

Grand strategy matrix dipilih sebagai pendekatan dalam memetakan laboratorium TI-UAI karena solusi yang ditawarkan bersifat kuantitatif, sehingga pengambilan keputusan akan lebih dilakukan pada saat penentuan strategi pengembangan laboratorium TI-UAI. Alur pemetaan disajikan pada Gambar 2.

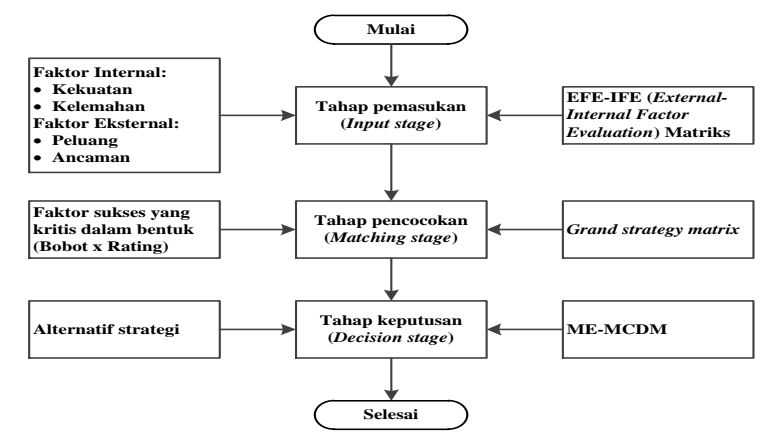

Gambar 2. Alur Pemetaan Laboratorium TI -UAI 


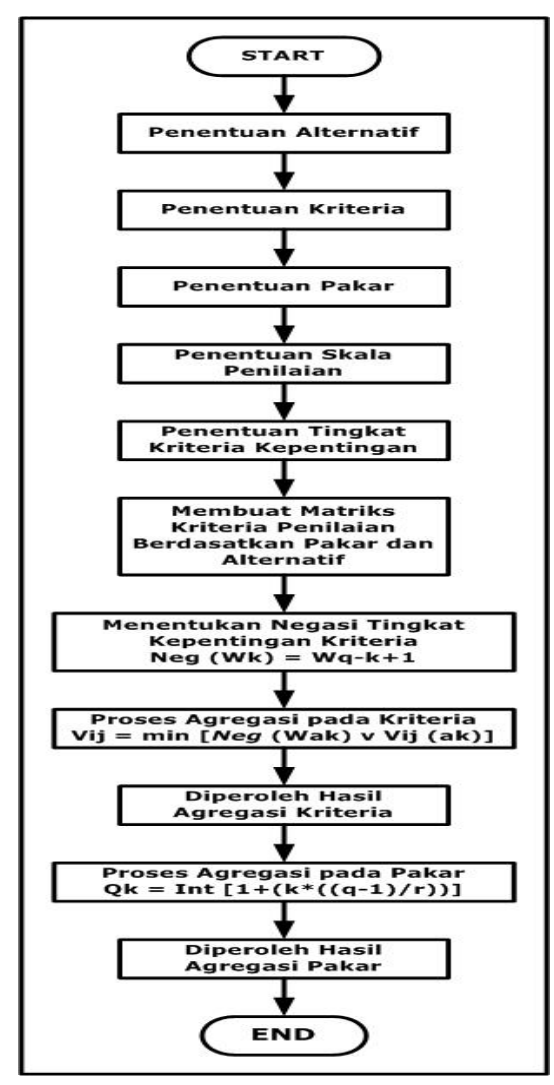

Gambar 3. Alur Penyelesaian ME-MCDM

Perumusan strategi yang disusun berdasarkan alternatif strategi dikembangkan dengan menggunakan pendekatan ME-MCDM. Pendekatan ini dipilih karena menggunakan pendapat pakar yang sesuai bidangnya, dan penggabungan pendapat yang tidak menyulitkan, karena pendapat akan diminta dalam bentuk kualitatif bukan kuantitatif. Gambar prosedur penggunaan ME-MCDM ditampilkan pada Gambar 3 [4].

Seperti telah disebutkan di atas, bahwa pakar yang akan diminta pendapat terdiri dari 3 orang, yaitu:

1. Bapak Ir. Syarif Hidayat, MEngSc.,MM. selaku Kepala Prodi TI-UAI

2. Ibu Widya Tanjung, ST.,MT.,MBA. selaku Laboran Lab TI-UAI

3. Bapak Drs. Amir Faisal, MM. selaku Kepala Biro Sarana dan Prasarana UAI

\section{HASIL DAN PEMBAHASAN}

\subsection{Analisis Kondisi Laboratorium TI-UAI Saat Ini}

Analisis yang dilakukan terhadap kondisi laboratorium saat ini adalah pemanfaatan
Tabel 1. Laboratorium TI-UAI

\begin{tabular}{clccc}
\hline No. & \multicolumn{1}{c}{ Nama Laboratorium } & Kapasitas & $\begin{array}{c}\text { Luas } \\
\left(\mathrm{m}^{2}\right)\end{array}$ & Ruang \\
\hline 1. & Laboratoratorium Teknik Industri & 15 & 35 & 611 \\
2. & Laboratorium Ergonomi & 10 & 24 & 034 \\
3. & Laboratorium Manufaktur & 12 & 40 & 035 \\
\hline
\end{tabular}

Tabel 2. Fasilitas bersama Praktikum TI

\begin{tabular}{lllccc}
\hline No. & Nama Fasilitas & \multicolumn{1}{c}{ Jenis Praktikum } & Kapasitas & $\begin{array}{c}\text { Luas } \\
\left(\mathrm{m}^{2}\right)\end{array}$ & Ruang \\
\hline 1. & Ruang Kelas & $\begin{array}{l}\text { 1. Pengendalian Kualitas } \\
\text { 2. Dasar Pemrograman }\end{array}$ & 45 & & 511 \\
& & & \\
& & & \\
& & & \\
& & Ponsep \\
& 4. Sistem Dinamik & & \\
\hline 2. & Pusat Komputer & Simulasi Komputer & 28 & 616 \\
\hline 3. & Amphiteater & Menggambar Teknik & 40 & $317 \mathrm{C}$ \\
\hline
\end{tabular}

laboratorium, kapasitas, penjadwalan, pengembangan modul dan sarana prasarana. TIUAI saat ini memiliki 3 laboratorium mandiri, dan 1 laboratorium yang digunakan sebagai fasilitas bersama.

Ketiga laboratorium yang dimiliki secara mandiri oleh prodi ini adalah Laboratorium Teknik Industri (Lab TI), Ergonomi (Lab Ergo) dan Proses Manufaktur (Lab Prosman). Ketiga laboratorium digunakan oleh seluruh mahasiswa TI yang akan melaksanakan praktikum.

Setiap praktikum diasuh oleh seorang asisten yang ditunjuk oleh Prodi. Lab TI saat ini memiliki seorang laboran. Laboran ini bertugas untuk mengkoordinasi segala kegiatan praktikum seperti berkoordinasi dengan Prodi dan asisten demi lancarnya pelaksanaan semua kegiatan praktikum. Laboran juga bertugas menyiapkan Standar Operasional Prosedur (SOP) Laboratorium.

SOP yang saat ini sudah tersedia dan dilaksanakan adalah (1). SOP Prosedur praktikum, (2) SOP tata cara pelaksanaan pre test, (3) Post test, (4) SOP pengajuan dana untuk asisten, (5) SOP perawatan lab, (6) SOP rekrutmen asisten, (7) SOP peminjaman ruang, dan (8) SOP peminjaman buku. Informasi mengenai kapasitas, luas lantai dan lokasi laboratorium disajikan pada Tabel 1. Hanya Lab TI yang berlokasi di lantai 6, sedangkan Lab Ergo dan Prosman terletak di Basement Lantai 2.

Uraian pelaksanaan praktikum di fasilitas bersama diuraikan pada Tabel 2. Pada tabel ini juga dijelaskan kapasitas, luas ruang dan lokasi ruangan di UAI. Pelaksanaan praktikum menggambar teknik di ruang Amphiteater, karena di ruang ini memiliki meja yang dapat difungsikan sebagai meja gambar 
teknik. Sebagai dampak karena prodi TI belum memiliki meja gambar di Lab TI.

Berdasarkan data luas ruangan dan kapasitas yang diuraikan pada Tabel 1 dan 2, maka dapat diketahui besarnya rasio ideal untuk penggunaan ketiga laboratorium bagi mahasiswa prodi TI. Nilai rasio ideal disajikan pada Tabel 3 .

Untuk mengetahui nilai utilisasi penggunaan laboratorium, terlebih dahulu harus diketahui alokasi praktikum yang dilaksanakan di masingmasing laboratorium. Tabel 4 menyajikan alokasi ruang laboratorium berdasarkan jenis praktikum yang dilaksanakan prodi TI.

Tiga jenis praktikum dilaksanakan pada lebih dari satu ruang laboratorium, yaitu (1) Praktikum Ergonomi, (2) Statistika Industri, dan (3) Perancangan Teknik Industri II. Sedangkan empat jenis praktikum dilaksanakan di ruang kelas, yaitu (1) Pengendalian Kualitas, (2) Dasar Pemrograman, (3) Konsep Pengembangan Produk, dan (4) Sistem Dinamik.

Praktikum Menggambar Teknik dilaksanakan di ruang Amphiteater karena ruang ini memiliki jenis meja yang tidak sama dengan meja ruang kelas, panjang dan lebarnya dapat dimanfaatkan untuk kegiatan menggambar teknik. Karena prodi TI tidak memiliki fasilitas meja gambar, maka praktikum ini dilaksanakan di ruang ini. Uraian lengkap alokasi pembagian ruangan berdasarkan jenis praktikum disajikan pada Tabel Lampiran 1.

Untuk mengetahui besarnya rasio masing-masing kegiatan praktikum di laboratorium akan ditampilkan pada Tabel Lampiran 2. Rasio dihitung berdasarkan luas ruangan dan jumlah praktikan yang memanfaatkan ruang laboratorium. Tabel Lampiran 2 berikut menampilkan rendahnya nilai rasio saat ini, jika dibandingkan dengan rasio ideal.

Tabel 3. Rasio Ideal Penggunaan Lab TI-UAI

\begin{tabular}{llrcc}
\hline No. $\quad$ Nama Laboratorium & Kapasitas & $\begin{array}{r}\text { Luas } \\
\left(\mathrm{m}^{2}\right)\end{array}$ & Rasio \\
\hline 1. Laboratoratorium Teknik Industi & 15 & 35 & 2,3 \\
2. Laboratorium Ergonomi & 10 & 24 & 2,4 \\
3. Laboratorium Manufaktur & 12 & 40 & 3,3 \\
4. Ruang Kelas & 45 & 64 & 1,4 \\
5. Pusat Komputer & 28 & 35 & 1,23 \\
6. Amphiteater & 40 & 53 & 1,3 \\
\hline
\end{tabular}

Berikut ini adalah contoh perhitungan rasio untuk jenis Praktikum Ergonomi di Lab Ergo. Terlihat bahwa nilai rasio lebih rendah rasio ideal. Rasio ideal adalah 2,4 sedangkan rasio Lab Ergo untuk Praktikum Ergonomi hanya 0,5. Maka, strategi yang saat ini telah dilaksanakan oleh Prodi TI adalah membagi pelaksanaan praktikum ke dalam beberapa shift, yaitu 2 hingga 3 shift.

$$
\text { Rasio Ideal Lab Ergo }=\frac{\text { Lwas ruangan }}{\text { jumlah prahtikan }}=\frac{24}{10}=2,3
$$

Rasio Lab Ergo $=\frac{\text { Luas rwangan }}{\text { jwmiah prahtikan }}=\frac{24}{44}=0,5$

Dua jenis pelaksanaan praktikum yang harus dibagi menjadi 3 shift adalah praktikum yang dilaksanakan di Lab Ergo, yaitu (1) Praktikum Ergonomi dan (2) Praktikum Pengendalian Kualitas. Seperti halnya Praktikum Ergonomi, demikian pula Praktikum Pengendalian Kualitas, yang rasionya rendah yaitu 1,0 .

Oleh sebab itu, praktikum ini juga dibagi menjadi 3 shift. Sehingga setiap shift dapat mencapai rasio rata-rata 2,0. Perincian rasio praktikum yang sudah dihitung diuraikan pada Tabel Lampiran 3.

Berdasarkan Tabel Lampiran 3 terlihat bahwa pembagian shift terhadap jenis praktikum tertentu cukup mengatasi masalah penjadwalan yang terjadi saat ini. Tetapi hal ini tidak akan dapat dipertahankan jika melihat tren mahasiswa Prodi TI-UAI yang meningkat setiap tahunnya.

Berdasarkan data yang disajikan pada Tabel Lampiran 4, diketahui bahwa utilisasi penggunaan ruang Lab Ergo adalah 18 jam, Lab TI adalah 48 jam, Lab Prosman adalah 6 jam, Puskom adalah 3 jam, Kelas adalah 8 jam dan Amphi adalah 2 jam. Penggunaan ruang di UAI adalah Senin hingga Jum'at dan dimulai pukul 08.00 hingga 16.00, atau 5 hari dengan durasi 8 jam per hari. Total penggunaan ruang maksimal adalah 40 jam.

Sementara itu, berdasarkan Tabel Lampiran 4 terdapat satu ruang laboratorium yang penggunaannya memenuhi batas maksimal dari utilisasi penggunaan ruang dalam satuan waktu jam per minggu, yaitu Laboratorium Teknik Industri yang terletak di 611 . Hal ini menunjukkan perlunya 
strategi penjadwalan yang dapat mengatasi permasalahan ini.

\subsection{Pemetaan Laboratorium Teknik Industri}

Pemetaan laboratorium TI-UAI akan dilaksanakan berdasarkan benchmark dengan 5 PTS, yaitu Universitas Trisakti, Indonusa Esa Unggul, UNIKA Atmajaya, Tarumanagara dan Universitas Pasundan.

Benchmark kepada 5 PTS dilakukan terhadap: (1) Jenis praktikum, (2) Fasilitas, sarana dan prasarana laboratorium, (3) Staf, (4) Modul dan pengembangannya, (5) Penelitian dan kerjasama dan (6) Strategi pengembangan laboratorium.

Berdasarkan hasil benchmark dengan Universitas Trisakti, Indonusa Esa Unggul, UNIKA Atmajaya, Tarumanagara dan Universitas Pasundan, maka dilakukan pemetaan terhadap kelima PTS ini termasuk di dalamnya menempatkan Prodi TI-UAI. Tabel Lampiran 5 digunakan untuk menguraikan hasil pemetaan terhadap kelima PTS yang memiliki Prodi TI. Pemetaan dilakukan berdasarkan: (1) Pelaksanaan praktikum, (2) Jenis Praktikum, (3) Fasilitas, Sarana dan Prasarana, (4) Sumber Daya Manusia, (5) Modul dan Pengembangannya, (6) Penelitian, (7) Kerjasama, dan (8) Strategi Pengembangan.

\subsection{Perumusan Strategi}

Strategi pengembangan laboratorium dilakukan melalui perumusan strategi berdasarkan tahap pemasukan (the input stage), tahap pencocokan (the matching stage), dan tahap pengambilan keputusan (the decision stage). Tahap pemasukan menentukan faktor-faktor penting yang berasal dari dalam TIUAI, terutama lab. Tahap pencocokan dilakukan dengan Grand Strategy Matrix. Penentuan berdasarkan pengambilan keputusan akan strategi yang akan dilaksanakan adalah menggunakan MEMCDM.

Tahap pemasukan merupakan tahap awal dalam rangka menentukan faktor lingkungan internal dan eksternal yang berpengaruh bagi dan dalam diri Lab TI-UAI. Faktor-faktor penting internal yang dimaksud adalah kekuatan dan kelemahan yang dimiliki lab TI-UAI. Sedangkan faktor-faktor penting eksternal yang dimaksud adalah peluang yang dihadapi dan ancaman yang siap menghadang perkembangan lab TI-UAI.
Pada tahap pemasukan, terdapat 7 faktor penting kekuatan, 8 faktor penting kelemahan, 4 faktor penting peluang, dan 5 faktor penting ancaman. Faktor penting yang berjumlah 24 itu kemudian dibobotkan. Pembobotan dilakukan oleh pakar yang ditunjuk. Total pembobotan dari faktor internal dan eksternal masing-masing tidak boleh lebih dari satu $(\leq 1)$.

Setelah pembobotan dilakukan, maka penentuan rating akan dilaksanakan berdasarkan hasil kuesioner yang dibagikan kepada Kaprodi TI, tiga orang dosen tetap, seorang laboran, 5 orang mahasiswa angkatan 2009/2010, dan 5 orang mahasiswa angkatan 2010/2011. Total kuesioner yang disebar adalah 15 kuesioner. Penyebaran kuesioner dilakukan oleh mahasiswa yang menjadi anggota tim penelitian ini.

Rating diisi oleh responden berdasarkan skala. Terdapat 5 skala dalam pengisian kuesioner ini, yaitu 5 artinya Sangat Penting, 4 artinya Penting, 3 artinya Cukup Penting, 2 artinya Tidak Penting, dan 1 artinya Sangat Tidak Penting. Hasil perhitungan berdasarkan penilaian IFE dan EFE disajikan pada Tabel Lampiran 6 dan 7.

Tahap pencocokan yang digunakan pada penelitian ini adalah menggunakan Grand Strategy Matrix. Setelah nilai matrix IFE dan EFE diketahui, maka nilainya dimasukkan ke dalam koordinat matriks. Sumbu X adalah faktor kekuatan dan kelemahan. Sumbu Y adalah faktor peluang dan ancaman.

Koordinat yang diperoleh untuk nilai faktor kekuatan dan kelemahan adalah:

Koordinat $\mathrm{X}=$ faktor kekuatan - faktor kelemahan

$$
\begin{aligned}
& =2,19-1,71 \\
& =0,48
\end{aligned}
$$

Koordinat yang diperoleh untuk nilai faktor peluang dan ancaman adalah:

Koordinat $\mathrm{Y}=$ faktor peluang - faktor ancaman

$$
\begin{aligned}
& =2,46-1,56 \\
& =0,90
\end{aligned}
$$

Koordinat yang diperoleh untuk Grand Strategy Matrix adalah $(0,48: 0,90)$. Koordinat tersebut berada pada kuadran I. Hasil titik koordinat disajikan pada Gambar 4. Kuadran I merupakan posisi strategik terbaik. Konsentrasi terus menerus pada pasar saat ini dengan strategi Penetrasi Pasar, Pengembangan Pasar dan Pengembangan Produk merupakan strategi yang tepat. 


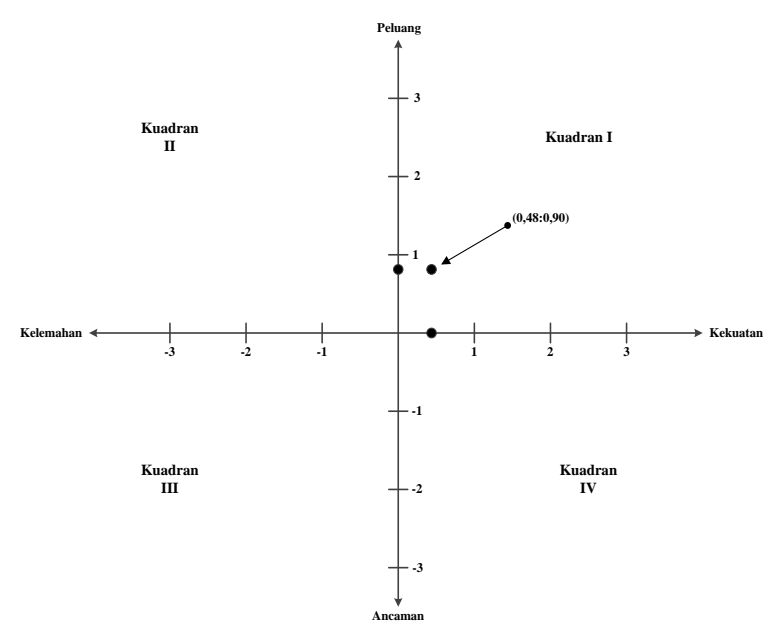

Gambar 4. Grand Strategy Matrix

Jika sumber daya berlebihan, maka Integrasi ke belakang, Integrasi ke depan atau Integrasi horisontal merupakan strategi yang efektif. Pada kuadran ini, perusahaan dapat mengambil manfaat dari peluang eksternal di berbagai area dan dapat bertindak agresif dalam menghadapi risiko jika memang diperlukan. Strategi Diversifikasi Konsentrik diterapkan untuk mengurangi resiko dari strategi produk tunggal. [5]

[5] menyatakan adanya 7 strategi yang dapat diperhitungkan dalam kuadran I ini. Ketujuh strategi tersebut adalah:

1. Pengembangan pasar

2. Penetrasi pasar

3. Pengembangan produk

4. Integrasi ke depan

5. Integrasi ke belakang

6. Integrasi horisontal

7. Diversifikasi konsentrik

\subsection{Pengambilan Keputusan Alternatif Strategi}

Sebelum dilakukan pengambilan keputusan untuk menentukan strategi pengembangan laboratorium TI-UAI, ketujuh strategi yang tercantum pada kuadran I akan diseleksi berdasarkan brainstorming dengan Kaprodi, dosen tetap dan laboran. Strategi yang dimaksud adalah: (1) Penetrasi pasar, (2) Pengembangan pasar dan (3) Pengembangan produk.

Strategi integrasi tidak dimasukkan dalam alternatif pemilihan strategi pengembangan lab TI, karena berdasarkan analisis kondisi saat ini bahwa SDM yang tersedia untuk pengembangan lab masih sangat terbatas. Demikian pula dengan strategi diversifikasi konsentrik, tidak dimasukkan sebagai salah satu alternatif strategi pengembangan lab TIUAI, karena untuk masa 3 tahun ke depan lab TI masih akan fokus untuk menguatkan keberadaannya dan mengembangkan perangkat sarana serta prasarana yang ada.

Strategi penetrasi pasar menjadi salah satu strategi yang dipilih untuk menjadi alternatif pengembangan strategi lab TI, karena dalam rangka mengimplementasi "Enterprising University" Prodi TI-UAI berusaha mengenalkan lab TI untuk dapat dimanfaatkan sebagai pelatihan/workshop bagi pengguna internal, dan eksternal khususnya. Tujuannya adalah untuk memperoleh pendapatan sendiri bagi Prodi TI untuk mengembangkan program pengembangan yang belum dapat ditanggung oleh UAI. Pengenalan dapat dilakukan melalui promosi di Website UAI ataupun media sosial yang dimiliki Dosen Tetap dan Laboran.

Strategi pengembangan pasar yang termasuk dalam salah satu alternatif strategi pengembangan lab adalah mengembangkan sarana dan prasarana Lab TI sesuai dengan standar Dikti dengan cara aktif mengikuti hibah/grant/pendanaan yang dikompetisikan baik oleh pemerintah maupun swasta untuk pengadaan kelengkapan sarana dan prasarana lab. Selain hibah/grant/pendanaan, pengembangan dapat dilakukan dengan menjalin kerjasama antara TI-UAI dengan industri manufaktur maupun jasa.

Strategi pengembangan produk yang termasuk dalam salah satu alternatif strategi pengembangan lab adalah melaksanakan secara aktif kegiatan penelitian -dosen dan mahasiswa- dengan memanfaatkan laboratorium yang sudah saat ini. Dan dengan penelitian, dapat diperoleh inovasi terhadap alat manufaktur ataupun aplikasi yang dibuat secara mandiri sehingga hak paten dapat diperoleh. Dengan perolehan hak paten ini tentunya akan meningkatkan akreditasi dan pendapatan prodi karena alat dan aplikasi yang dijual adalah paten milik Prodi.

Alternatif strategi pengembangan lab akan dipilih menggunakan pendekatan Non Numeric Multi Experts Multi Criteria Decision Making (MEMCDM). Tahapan pengolahannya diawali dengan mengidentifikasi alternatif strategi yang akan dipilih. Alternatif strategi diuraikan pada Tabel 4 [6].

Setelah alternatif diidentifikasi, maka tingkat kepentingan kriteria akan ditetapkan prioritas 
Tabel 4. Alternatif Strategi

\begin{tabular}{cl}
\hline Alternatif ke- & \multicolumn{1}{c}{ Strategi } \\
\hline 1 & Penetrasi pasar \\
2 & Pengembangan pasar \\
3 & Pengembangan produk \\
\hline
\end{tabular}

kepentingannya dengan menggunakan skala yang disajikan pada Tabel 5 .

Tingkat kepentingan kriteria dinilai oleh 3 pakar seperti yang telah disebutkan sebelumnya. Tabel 6 menyajikan hasil pendapat pakar untuk tingkat kepentingan kriteria, sekaligus diuraikan penggabungan pendapat pakar dengan menggunakan nilai crips dari rata-rata geometri atau Center of Geometry.

Data pada Tabel 6 diolah dengan Agregasi Kriteria - Pakar. Hasil Agregasi Kriteria disajikan pada Tabel 7.

Tabel 7 menunjukkan bahwa strategi pengembangan yang tepat untuk Lab TI-UAI adalah melakukan penetrasi pasar dan pengembangan produk. Melalui penetrasi pasar, prodi ini akan mampu menghasilkan pemasukan sendiri, tanpa tergantung dari banyaknya jumlah yang masuk. Pemasukan dapat diperoleh melalui Pelaksanaan Training, workshop atau in house training.

Pelaksanaan training yang mungkin ditawarkan adalah: (1) Enterprise Resource Planning, (2) Penggunaan Software seperti AutoCad, Inventor, SPSS, Promodel, Power Simulation, Matlab, (3) Interpersonal skill, (4) Production planning, (5) Statistik, (6) Manajemen Operasional (7) Manajemen proyek, dan materi lain yang terkait dengan keilmuan dan kompetensi TI-UAI.

Dengan melaksanakan strategi pengembangan produk artinya prodi $\mathrm{Ti}$ sekaligus menerapkan budaya riset bagi dosen dan mahasiswanya. Dengan mengembangkan produk dari hasil penelitian antara dosen dan mahasiswa akan meningkatkan ketrampilan mahasiswa dalam keilmuan teori dan praktis khususnya.
Tabel 5. Tingkat Kepentingan Kriteria

\begin{tabular}{ccc}
\hline Kriteria ke- & \multicolumn{2}{c}{ Skala } \\
\hline 1 & SP & Sangat Penting \\
2 & P & Penting \\
3 & S & Sedang \\
4 & KP & Kurang Penting \\
5 & TP & Tidak Penting \\
\hline
\end{tabular}

Tabel 6. Pendapat Pakar terhadap Alternatif Strategi Pengembangan Lab TI-UAI

\begin{tabular}{ccccccc}
\hline \multirow{2}{*}{$\begin{array}{c}\text { Pakar } \\
\text { ke- }\end{array}$} & \multirow{2}{*}{$\begin{array}{c}\text { Alternatif } \\
\text { ke- }\end{array}$} & \multicolumn{6}{c}{ Kriteria Penilaian } \\
\cline { 3 - 7 } & & $\begin{array}{c}\text { Kriteria } \\
\text { ke-1 }\end{array}$ & $\begin{array}{c}\text { Kriteria } \\
\text { ke-2 }\end{array}$ & $\begin{array}{c}\text { Kriteria } \\
\text { ke-3 }\end{array}$ & $\begin{array}{c}\text { Kriteria } \\
\text { ke-4 }\end{array}$ & $\begin{array}{c}\text { Kriteria } \\
\text { ke-5 }\end{array}$ \\
\hline \multirow{3}{*}{1} & 1 & $\mathrm{P}$ & $\mathrm{P}$ & $\mathrm{KP}$ & $\mathrm{KP}$ & $\mathrm{KP}$ \\
& 2 & $\mathrm{P}$ & $\mathrm{P}$ & $\mathrm{KP}$ & $\mathrm{P}$ & $\mathrm{P}$ \\
& 3 & $\mathrm{P}$ & $\mathrm{P}$ & $\mathrm{P}$ & $\mathrm{P}$ & $\mathrm{P}$ \\
\hline \multirow{3}{*}{2} & 1 & $\mathrm{SP}$ & $\mathrm{SP}$ & $\mathrm{S}$ & $\mathrm{SP}$ & $\mathrm{SP}$ \\
& 2 & $\mathrm{SP}$ & $\mathrm{SP}$ & $\mathrm{S}$ & $\mathrm{P}$ & $\mathrm{P}$ \\
& 3 & $\mathrm{P}$ & $\mathrm{P}$ & $\mathrm{KP}$ & $\mathrm{P}$ & $\mathrm{P}$ \\
\hline \multirow{3}{*}{3} & 1 & $\mathrm{P}$ & $\mathrm{P}$ & $\mathrm{P}$ & $\mathrm{P}$ & $\mathrm{P}$ \\
& 2 & $\mathrm{P}$ & $\mathrm{P}$ & $\mathrm{KP}$ & $\mathrm{P}$ & $\mathrm{P}$ \\
& 3 & $\mathrm{P}$ & $\mathrm{KP}$ & $\mathrm{P}$ & $\mathrm{P}$ & $\mathrm{KP}$ \\
\hline
\end{tabular}

Tabel 7. Hasil Agregasi Kriteria - Pakar

\begin{tabular}{lcccc}
\hline & \multicolumn{2}{c}{$\begin{array}{c}\text { Hasil Agregasi } \\
\text { Penilaian Pakar } \\
\text { Alternatif Strategi }\end{array}$} & $\begin{array}{c}\text { Agregasi } \\
\text { Pakar }\end{array}$ \\
\cline { 2 - 4 } & \multicolumn{3}{c}{ ke- } & \\
\hline Penetrasi pasar & $\mathrm{S}$ & $\mathrm{S}$ & $\mathrm{P}$ & $\mathrm{P}$ \\
Pengembangan pasar & $\mathrm{S}$ & $\mathrm{S}$ & $\mathrm{S}$ & $\mathrm{S}$ \\
Pengembangan produk & $\mathrm{P}$ & $\mathrm{S}$ & $\mathrm{S}$ & $\mathrm{P}$ \\
\hline
\end{tabular}

\section{KESIMPULAN}

\subsection{Kesimpulan}

Lab TI-UAI memiliki rasio luas ruangan berbanding jumlah mahasiswa yang tidak ideal. Strategi yang saat ini digunakan menjadwalkan praktikum adalah menetapkan kebijakan sistem shift. Selain rasio yang belum ideal, keterbatasan sarana terbukti dari utilitas waktu pengunaan LabTI yang melebihi utilitas waktu penggunaan ruang di UAI.

Analisis IFE dan EFE menghasilkan koordinat X sebagai faktor penting kekuatan dan kelemahan Lab 
TI dengan nilai sebesar 0,48 . Sedangkan koordinat Y sebagai faktor penting peluang dan ancaman dengan nilai sebesar 0,90 .

Atas dasar nilai koordinat $(0,48: 0,90)$ maka, Grand strategy matrix yang digunakan dalam tahap The matching stage menempatkan Lab TI-UAI ke dalam kuadran I. Kuadran I merupakan posisi terbaik dalam mengembangkan unitnya, yang dalam hal ini adalah Lab TI. Strategi yang dihasilkan dari brainstorming adalah strategi penetrasi pasar, pengembangan pasar dan pengembangan produk.

Strategi pengembangan Lab TI-UAI yang berhasil ditentukan dengan pendekatan penggabungan pakar berdasarkan Non Numeric ME-MCDM adalah strategi penetrasi pasar dan pengembangan produk dengan bobot kepentingan masing-masing $\mathrm{P}$ atau Penting.

\subsection{Saran}

Dalam rangka menghadapi akreditasi BAN-PT 2014 mendatang, prodi TI sudah harus mempersiapkan strategi untuk mengembangkan labnya. Kedua strategi ini akan sangat strategis jika diterapkan dalam pengembangannya, mengingat tren jumlah mahasiswa yang terus meningkat hingga saat ini.

Pendekatan pengambilan keputusan dengan sistem fuzzy dapat digunakan untuk pengembangan penelitian ini. Penelitian ini dapat dikembangkan untuk strategi pengembangan laboratorium Prodi lain di UAI.

Pendekatan manajemen strategi selain Grand Strategy Matrix dapat digunakan untuk melakukan formulasi strategi. Matriks Boston Consulting Group atau Matriks General Electric dapat digunakan sebagai salah satu alternatif.

Untuk mengetahui evaluasi penggunaan strategi pengembangan Lab TI yang telah diusulkan, Prodi
TI-UAI dapat menggunakan pendekatan simulasi untuk memprediksi kondisinya pada 3 hingga 5 tahun mendatang. Pendekatan simulasi yang mungkin digunakan adalah Analisis Sistem Dinamik dan Pemodelan Sistem dengan bantuan software Promodel.

\section{UCAPAN TERIMAKASIH}

Terimakasih disampaikan kepada LP2M-UAI atas pendanaan research grant tahun anggaran 2012/2013, sehingga banyak masukan dan fakta baru yang dapat diketahui oleh Prodi TI-UAI dalam rangka pengembangannya menjadi prodi yang unggul.

\section{DAFTAR PUSTAKA}

[1] Buku Pedoman Akademik Universitas Al Azhar Indonesia, UAI Press, 2011, Jakarta.

[2] Wignjosoebroto, S., Revitalisasi Peran dan Fungsi Laboratorium Ergonomi, http://msritomo.blogspot. com/2011. (diakses pada tanggal 19 Februari 2012)

[3] Khotimah, Siti, Perumusan Strategi bagi Perguruan Tinggi Swasta untuk Meraih Keunggulan Bersaing (Studi Kasus pada Universitas Merdeka Malang) http://elibrary.ub.ac.id/handle/123456789/331 32 (diakses pada tanggal 10 Juni 2012)

[4] Yager, R. R., "Non-Numeric Multi-Criteria Multi-Person Decision Making," International Journal of Group Decision Making and Negotiation 2, 81-93, 1993

[5] David, F.R. 2001 Strategic Management: Concept and Cases. Pearson.

[6] N. Nurhasanah, D. Januwar. Jurnal Teknik Industri. Universitas Trisakti. 101-109. 2012. 
Tabel Lampiran 1. Alokasi Ruangan berdasarkan Jenis Praktikum

\begin{tabular}{|c|c|c|c|c|c|c|}
\hline \multirow[b]{2}{*}{ Jenis Praktikum } & \multicolumn{6}{|c|}{ Nama Ruang Laboratorium } \\
\hline & $\begin{array}{l}\text { Ergonomi } \\
\quad(034)\end{array}$ & $\begin{array}{c}\text { Teknik } \\
\text { Industri } \\
(611)\end{array}$ & $\begin{array}{c}\text { Proses } \\
\text { Manufaktur } \\
(035) \\
\end{array}$ & $\begin{array}{c}\text { Pusat } \\
\text { Komputer } \\
(616) \\
\end{array}$ & Kelas & $\begin{array}{c}\text { Amphiteater } \\
(317 \mathrm{C})\end{array}$ \\
\hline Ergonomi & $\mathrm{x}$ & $\mathrm{x}$ & & & & \\
\hline Proses Manufaktur & & & $\mathrm{x}$ & & & \\
\hline Statistika Industri & $\mathrm{x}$ & $\mathrm{x}$ & & & & \\
\hline Pengendalian Kualitas & $\mathrm{x}$ & & & & $\mathrm{x}$ & \\
\hline Perencanaan Tata Letak Pabrik & & $\mathrm{x}$ & & & & \\
\hline Dasar Pemrograman & & & & & $\mathrm{x}$ & \\
\hline Simulasi Komputer & & & & $\mathrm{x}$ & & \\
\hline Perencanaan dan Pengendalian Produksi & & $\mathrm{x}$ & & & & \\
\hline Perancangan Sistem Kerja \& Ergonomi & & $\mathrm{x}$ & & & & \\
\hline Konsep Pengembangan Produk & & & & & $\mathrm{x}$ & \\
\hline Menggambar Teknik & & & & & & $\mathrm{x}$ \\
\hline Sistem Dinamik & & & & & $\mathrm{x}$ & \\
\hline Perencanaan Sumberdaya Perusahaan & & $\mathrm{x}$ & & & & \\
\hline Perancangan Teknik Industri - I & & $\mathrm{x}$ & & & & \\
\hline Perancangan Teknik Industri - II & $\mathrm{x}$ & $\mathrm{x}$ & & & & \\
\hline
\end{tabular}

Tabel Lampiran 2. Rasio Luas Laboratorium dibandingkan Jumlah Mahasiswa yang dilaksanakan di TI-UAI

\begin{tabular}{|c|c|c|c|c|c|c|}
\hline \multirow[b]{2}{*}{ Jenis Praktikum } & \multicolumn{6}{|c|}{ Rasio Luas Laboratorium : Jumlah Mahasiswa } \\
\hline & $\begin{array}{l}\text { Ergonomi } \\
\quad(034)\end{array}$ & $\begin{array}{c}\text { Teknik } \\
\text { Industri } \\
(611)\end{array}$ & $\begin{array}{c}\text { Proses } \\
\text { Manufaktur } \\
(035)\end{array}$ & $\begin{array}{c}\text { Pusat } \\
\text { Komunikasi } \\
(616)\end{array}$ & Kelas & $\begin{array}{c}\text { Amphiteater } \\
(317 \mathrm{C})\end{array}$ \\
\hline Ergonomi & 0,5 & 0,8 & & & & \\
\hline Proses Manufaktur & & & 1,0 & & & \\
\hline Statistika Industri & & 1,0 & & & & \\
\hline Pengendalian Kualitas & 1,0 & & & & 1,8 & \\
\hline Perencanaan Tata Letak Pabrik & & 1,8 & & & & \\
\hline Dasar Pemrograman & & & & & 1,1 & \\
\hline Simulasi Komputer & & & & 1,1 & & \\
\hline Perencanaan dan Pengendalian Produksi & & 1,4 & & & & \\
\hline Perancangan Sistem Kerja \& Ergonomi & & 1,2 & & & & \\
\hline Konsep Pengembangan Produk & & & & & 1,8 & \\
\hline Menggambar Teknik & & & & & & 1,6 \\
\hline Sistem Dinamik & & & & & 1,8 & \\
\hline Perencanaan Sumberdaya Perusahaan & & 1,8 & & & & \\
\hline Perancangan Teknik Industri - I & & 1,5 & & & & \\
\hline Perancangan Teknik Industri - II & & 1,5 & & & & \\
\hline
\end{tabular}


Tabel Lampiran 3. Rasio Luas Ruangan dibandingkan Jumlah Praktikan berdasarkan Shift Praktikum

\begin{tabular}{|c|c|c|c|c|c|c|c|c|c|c|c|}
\hline \multirow{3}{*}{$\begin{array}{c}\text { Jenis } \\
\text { Praktikum }\end{array}$} & \multicolumn{11}{|c|}{ Rasio Luas Laboratorium : Jumlah Mahasiswa } \\
\hline & \multicolumn{3}{|c|}{ Ergonomi } & \multicolumn{3}{|c|}{ Teknik Industri } & \multicolumn{2}{|c|}{$\begin{array}{c}\text { Proses } \\
\text { Manufaktur }\end{array}$} & \multirow{2}{*}{$\begin{array}{l}\text { Pusat } \\
\text { Komuni- } \\
\text { kasi }\end{array}$} & \multirow[t]{2}{*}{ Kelas } & \multirow{2}{*}{$\begin{array}{l}\text { Amphi- } \\
\text { teater }\end{array}$} \\
\hline & $\begin{array}{l}\text { Shift } \\
\text { I }\end{array}$ & $\begin{array}{l}\text { Shift } \\
\text { II }\end{array}$ & $\begin{array}{l}\text { Shift } \\
\text { III }\end{array}$ & $\begin{array}{l}\text { Shift } \\
\text { I }\end{array}$ & $\begin{array}{l}\text { Shift } \\
\text { II }\end{array}$ & $\begin{array}{c}\text { Shift } \\
\text { III }\end{array}$ & $\begin{array}{l}\text { Shift } \\
\text { I }\end{array}$ & $\begin{array}{c}\text { Shift } \\
\text { II }\end{array}$ & & & \\
\hline Ergonomi & 1,5 & 1,8 & 1,8 & 2,2 & 2,7 & 2,3 & & & & & \\
\hline Proses Manufaktur & & & & & & & 2,0 & 2,0 & & & \\
\hline Statistika Industri & & & & 2,9 & 2,9 & 3,5 & & & & & \\
\hline $\begin{array}{l}\text { Pengendalian } \\
\text { Kualitas }\end{array}$ & 2,0 & 2,0 & 2,2 & & & & & & & 1,8 & \\
\hline $\begin{array}{l}\text { Perencanaan Tata } \\
\text { Letak Pabrik }\end{array}$ & & & & 3,5 & 4,0 & & & & & & \\
\hline Dasar Pemrograman & & & & & & & & & & 1,1 & \\
\hline Simulasi Komputer & & & & & & & & & 1,1 & & \\
\hline $\begin{array}{l}\text { Perencanaan dan } \\
\text { Pengendalian } \\
\text { Produksi }\end{array}$ & & & & & & & & & & & \\
\hline $\begin{array}{l}\text { Perancangan Sistem } \\
\text { Kerja \& Ergonomi } \\
\text { Konsep }\end{array}$ & & & & 2,3 & 2,7 & & & & & & \\
\hline $\begin{array}{l}\text { Pengembangan } \\
\text { Produk }\end{array}$ & & & & & & & & & & 1,8 & \\
\hline Menggambar Teknik & & & & & & & & & & & 1,6 \\
\hline Sistem Dinamik & & & & & & & & & & 1,8 & \\
\hline $\begin{array}{l}\text { Perencanaan } \\
\text { Sumberdaya } \\
\text { Perusahaan }\end{array}$ & & & & 3,5 & 3,5 & & & & & & \\
\hline $\begin{array}{l}\text { Perancangan Teknik } \\
\text { Industri - I }\end{array}$ & & & & 2,9 & 2,9 & & & & & & \\
\hline $\begin{array}{l}\text { Perancangan Teknik } \\
\text { Industri - II }\end{array}$ & & & & 2,9 & 3,2 & & & & & & \\
\hline
\end{tabular}

Tabel Lampiran 4. Utilisasi Penggunaan Laboratorium

\begin{tabular}{lcccccc}
\hline \multirow{2}{*}{ Jenis Praktikum } & \multicolumn{5}{c}{ Utilisasi Penggunaan Laboratorium (jam/minggu) } \\
\cline { 2 - 6 } & Ergo & TI & Prosman & Puskom & Kelas & Amphi \\
\hline Ergonomi & 9 & 9 & - & - & - & - \\
Proses Manufaktur & - & - & 6 & - & - & - \\
Statistika Industri & - & 9 & - & - & - & - \\
Pengendalian Kualitas & 9 & - & - & - & 2 & - \\
Perencanaan Tata Letak Pabrik & - & 6 & - & - & - & - \\
Dasar Pemrograman & - & - & - & - & 2 & - \\
Simulasi Komputer & - & - & - & 3 & - & - \\
Perencanaan dan Pengendalian Produksi & - & - & - & - & - & - \\
Perancangan Sistem Kerja \& Ergonomi & - & 6 & - & - & - & - \\
Konsep Pengembangan Produk & - & - & - & - & 2 & - \\
Menggambar Teknik & - & - & - & - & - & 2 \\
Sistem Dinamik & - & - & - & - & 2
\end{tabular}


Perencanaan Sumberdaya Perusahaan

Perancangan Teknik Industri - I

Perancangan Teknik Industri - II

TOTAL

-

18

6
6
6

48
6
3

Tabel Lampiran 5. Pemetaan Laboratorium TI di Lima PTS

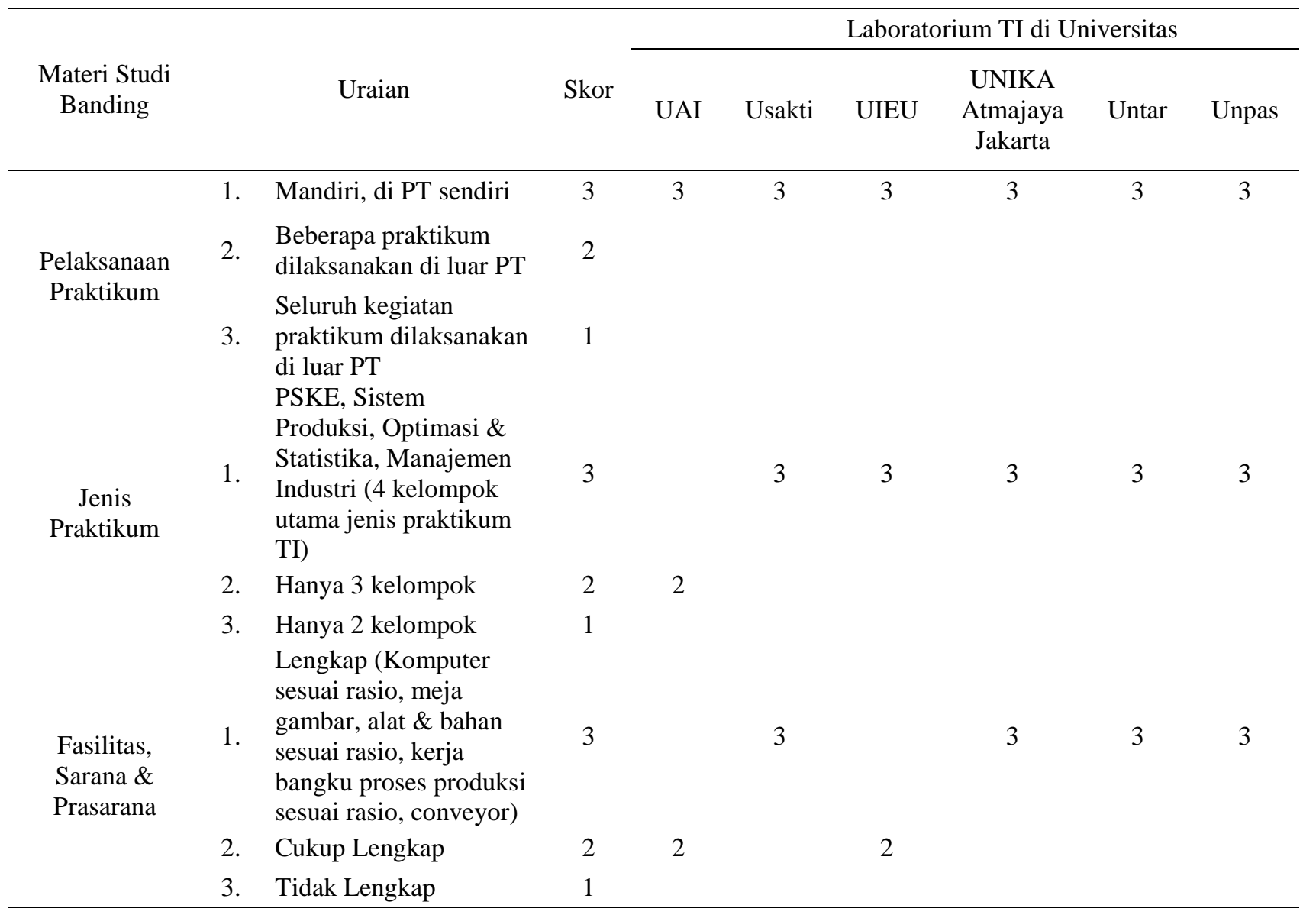

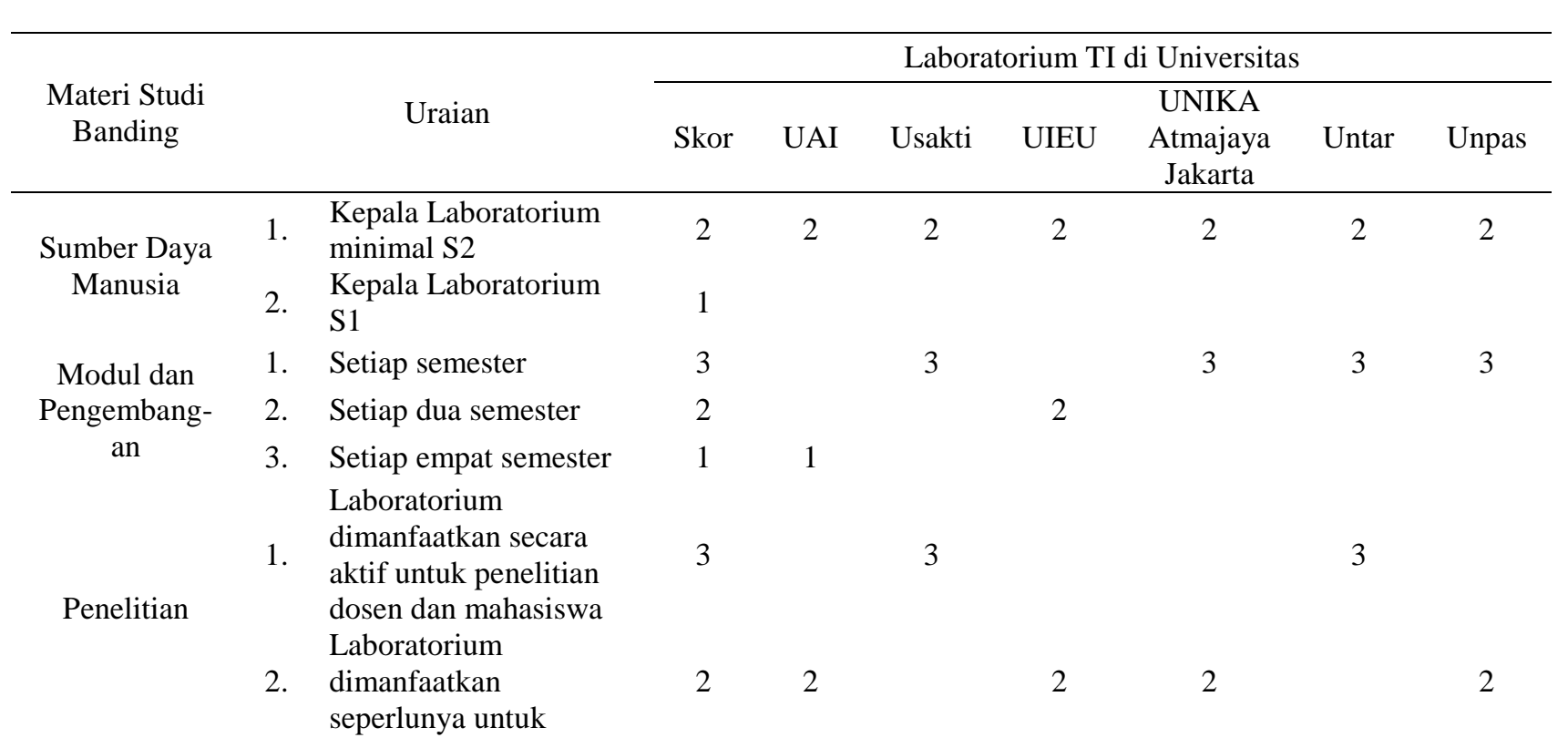




\begin{tabular}{|c|c|c|c|c|c|c|c|c|c|}
\hline & & $\begin{array}{l}\text { penelitian dosen dan } \\
\text { mahasiswa }\end{array}$ & & & & & & & \\
\hline & & $\begin{array}{l}\text { Laboratorium } \\
\text { tidak/belum }\end{array}$ & & & & & & & \\
\hline & 3. & $\begin{array}{l}\text { dimanfaatkan untuk } \\
\text { penelitian dosen dan } \\
\text { mahasiswa }\end{array}$ & 1 & & & & & & \\
\hline & 1. & $\begin{array}{l}\text { Sudah dilakukan } \\
\text { kerjasama untuk } \\
\text { meningkatkan fasilitas } \\
\text { laboratorium }\end{array}$ & 2 & 2 & & & & & \\
\hline Kerjasama & & $\begin{array}{l}\text { Belum dilakukan } \\
\text { kerjasama untuk }\end{array}$ & & & & & & & \\
\hline & 2. & $\begin{array}{l}\text { meningkatkan fasilitas } \\
\text { laboratorium }\end{array}$ & 1 & & 1 & 1 & 1 & 1 & 1 \\
\hline & 1. & $\begin{array}{l}\text { Pengembangan } \\
\text { dilakukan secara aktif } \\
\text { setiap semester }\end{array}$ & 3 & & 3 & & 3 & 3 & 3 \\
\hline $\begin{array}{c}\text { Strategi } \\
\text { Pengembangan }\end{array}$ & 2. & $\begin{array}{l}\text { Pengembangan } \\
\text { dilakukan secara aktif } \\
\text { setiap dua semester }\end{array}$ & 2 & 2 & & 2 & & & \\
\hline & 3. & $\begin{array}{l}\text { Pengembangan } \\
\text { dilakukan secara aktif } \\
\text { setiap empat semester }\end{array}$ & 1 & & & & & & \\
\hline & & TOTAL & & 17 & 22 & 18 & 21 & 22 & 21 \\
\hline
\end{tabular}

Tabel Lampiran 6. IFE Matriks

\begin{tabular}{|c|c|c|c|}
\hline Faktor-faktor Penting & \multirow{2}{*}{ Bobot } & \multirow{2}{*}{ Rating } & \multirow{2}{*}{ Bobot x Rating } \\
\hline Kekuatan & & & \\
\hline $\begin{array}{l}\text { Tingginya komitmen pimpinan dalam mengembangkan program studi } \\
\text { berikut laboratorium }\end{array}$ & 0,10 & 4,00 & 0,40 \\
\hline Koordinasi program studi dan laboratorium baik & 0,08 & 5,00 & 0,40 \\
\hline Sumberdaya laboratorium handal & 0,06 & 4,00 & 0,24 \\
\hline Inventaris peralatan praktikum terdokumentasi dengan baik & 0,05 & 4,00 & 0,20 \\
\hline SOP tersusun dengan baik & 0,08 & 4,00 & 0,32 \\
\hline Semua kegiatan praktikum dilaksanakan di UAI & 0,09 & 3,00 & 0,27 \\
\hline $\begin{array}{l}\text { Beberapa praktikum dilaksanakan dengan studi kasus langsung ke } \\
\text { industri }\end{array}$ & 0,09 & 4,00 & 0,36 \\
\hline Total & 0,55 & & 2,19 \\
\hline \multicolumn{4}{|l|}{ Kelemahan } \\
\hline Modul praktikum belum semuanya tersusun sesuai standar Dikti & 0,04 & $-4,00$ & $-0,16$ \\
\hline Rasio luas ruang:jumlah praktikan rendah & 0,09 & $-5,00$ & $-0,40$ \\
\hline Pemanfaatan laboratorium untuk riset dosen/mahasiswa masih rendah & 0,09 & $-4,00$ & $-0,36$ \\
\hline Belum memiliki Instruksi Kerja & 0,04 & $-3,00$ & $-0,12$ \\
\hline Software praktikum belum memiliki lisence & 0,07 & $-4,00$ & $-0,28$ \\
\hline Penjadwalan praktikum belum menggunakan TIK & 0,04 & $-4,00$ & $-0,16$ \\
\hline Jumlah personil laboran terbatas & 0,03 & $-1,00$ & $-0,03$ \\
\hline Jumlah komputer kurang dari rasio ideal & 0,05 & $-3,00$ & $-0,15$ \\
\hline Total & 0,45 & & $-1,71$ \\
\hline TOTAL & 1,00 & & \\
\hline
\end{tabular}


Tabel Lampiran 7. EFE Matriks

\begin{tabular}{|c|c|c|c|}
\hline Faktor-faktor Penting & Bobot & Rating & Bobot x Rating \\
\hline \multicolumn{4}{|l|}{ Peluang } \\
\hline Kerjasama dengan instansi internasional dan nasional & 0,20 & 4,00 & 0,80 \\
\hline Dana hibah pengembangan laboratorium dikompetisikan Dikti & 0,09 & 4,00 & 0,36 \\
\hline $\begin{array}{l}\text { Dana riset DP2M Dikti digunakan dengan memanfaatkan } \\
\text { laboratorium untuk meningkatkan utilisasi penggunaan laboratorium }\end{array}$ & 0,10 & 5,00 & 0,50 \\
\hline $\begin{array}{l}\text { Beberapa Industri di Jabodetabek bersedia menerima praktikan untuk } \\
\text { mengambil data dalam menyelesaikan tugas/laporan laboratorium }\end{array}$ & 0,20 & 4,00 & 0,80 \\
\hline TOTAL & $\mathbf{0 , 5 9}$ & & 2,46 \\
\hline \multicolumn{4}{|l|}{ Ancaman } \\
\hline Material laboratorium proses manufaktur relatif mahal & 0,09 & $-3,00$ & $-0,27$ \\
\hline Harga mesin untuk praktikum proses manufaktur relatif tinggi & 0,09 & $-4,00$ & $-0,36$ \\
\hline Laboratorium PTS lain lebih maju & 0,07 & $-3,00$ & $-0,21$ \\
\hline $\begin{array}{l}\text { Berpotensi praktikum dilaksananakan di luar UAI, jika jumlah } \\
\text { praktikan meningkat } 100 \% \text {, karena tidak mungkin melakukan } \\
\text { perluasan ruang laboratorium }\end{array}$ & 0,08 & $-4,00$ & $-0,32$ \\
\hline Penurunan angka akreditasi program studi & 0,08 & $-5,00$ & $-0,40$ \\
\hline Total & 0,41 & & $-1,56$ \\
\hline TOTAL & $\mathbf{1 , 0 0}$ & & \\
\hline
\end{tabular}

